\title{
Applying Geocritical Theory to the Study Abroad Learning Experience
}

\author{
Michael K. Walonen \\ Bethune-Cookman University \\ "A place belongs forever to whoever claims it hardest, remembers it most obsessively, wrenches it from itself, \\ shapes it, renders it, loves it so radically that he remakes it in his own image" Joan Didion
}

International study among U.S. college students reached an all-time high of 819,644 during the 2013-2014 academic year (Redden), inching ever-closer to the goal of one million annual participants set by the Congressional Lincoln Commission in 2006 (Wanner 85). And for good reason; recent studies have shown both that employers are coming to increasingly value study abroad experience among prospective employees and that study abroad may foster broad cognitive gains among its participants. In their survey of employer attitudes regarding international study, Stevan Trooboff et al. find that senior management and human resources officials, particularly those who have studied abroad themselves, hold study abroad experience in high esteem and rank the skills they see as fostered by international study very highly among those they wish their employees to possess $(20,21$, $24,28)$. At the same time, countless study abroad educators have anecdotally testified to increased academic performance and personal maturity among study abroad students, including Kenneth Wagner and Tony Magistrale, who claim that study abroad leads to a stronger sense of autonomy/selfconfidence, the adoption of a more broadly "political" perspective on social life, and the ability to shift cultural perspective and call into question ethnocentric values (132-139). Joshua S. McKeon goes even further, empirically documenting how among students with no prior international experience, study abroad leads to the adoption of more sophisticated, nuanced worldviews and learning strategies, and can thus help to close the learning gap these students can experience vis-à-vis more experientially privileged peers (42-43).

In the face of the almost four-fold increase in study abroad participation over the past seven years spurred on in part by these potential benefits, ${ }^{1}$ it is imperative to ask some pressing questions regarding how to optimize the study abroad experience, ensuring that students move beyond a superficially touristic mode of uninformed impressionistic response to their host locale into a more sophisticated engagement with its complex social, political, historical, and cultural particularities. In this spirit, this essay will use geocritical theory to inquire into the pedagogical uses and larger social functioning of texts that represent the places ${ }^{2}$ to which study abroad students flock in search of

${ }^{1}$ In 2006-2007 223,000 American students studied abroad (Wanner 85).

${ }^{2}$ As social geographer Yi Fu Tuan notes, "Place exists at different scales" (149), different points along a

continuum stretching from the immediate (place as immediate physical surroundings - residence, workplace, 
knowledge and experience. In doing so, it will ask what are some of the ways texts and the places they represent relate to each other, how do texts set up horizons of expectations regarding places to be encountered, and, as a function of these, how might these texts best be put to use in a study abroad educational context?

Geocriticism is an interdisciplinary mode of literary critical/social geographic inquiry reflective of the "spatial turn" in critical theory pioneered by such theorists as Michel Foucault, Henri Lefebvre, Gilles Deleuze/Felix Guattari, and Edward Soja. As defined by Robert T. Tally, one of its major proponents, geocriticism "is a way of looking at the spaces of literature, broadly conceived to include not only those places that readers and writers experience by means of texts but also the experience of space and place within ourselves. That is, geocriticism can examine how the ways in which we are situated in space determine the nature and quality of our existence in the world. With geocriticism, one emphasizes this inherent spatiality while also focusing one's critical gaze on those aspects of literature (and other texts not always deemed literary) that give meaning to our spatialized sense of being" (8). Central to geocriticism is Henri Lefebvre's observation in The Production of Space that spaces, which in being combined and taking on degrees of definition come to constitute place, are socially produced (27-39). Spaces and places are made out of the social "energies" and activities that animate them: the cultural practices, patterns of daily usage, aestheticized modes of arranging environments via architecture and landscape design, etc. that make one place unlike any other, but also out of the dialogical process of meaning attribution representational texts engage in . Therefore, reading copiously of the literature of a given place in a focused, engaged manner can help to sensitize students to this culturally constructed aspect of place, how the particular ways that human beings practice place serve to make it what it is.

"[P]laces teach us about how the world works and how our lives fit into the spaces we occupy," educational theorist David A. Gruenewald observes, "Further places make us: As occupants of particular places with particular attributes, our identity and our possibilities are shaped" (qtd in McCracken 126). So conceptualizing place is an essential means of understanding ourselves and our relation to the world, and thus it is important that our educational experiences foster a deeply reflective manner of doing so, particularly in a situation of deterritorialization like study abroad that holds the possibility of radically transforming senses of both self and world. Reading about place is, of course, integral to developing a sophisticated and variegated sense of place, just as writing about place is an essential means of solidifying, qualifying, and nuancing one's emergent conceptualizations of place. In her "Using Literature to Promote Cultural Fluency in Study Abroad Programs" Kandace Einbeck argues that first-hand exposure to foreign societies is not sufficient to build cultural fluency in students, but these experiences can be augmented through the study of the literature of the encountered place, given literature's capacity to function as "a magnificent cultural lens: it focuses our

neighborhood) to the more abstract and imaginary (place as region, nation, trans-national region). These different scales of place are mutually imbricated: one's sense of dwelling as home will be inflected by one's sense of nation as home and vice versa, for example. Throughout this essay the term "place" will be used broadly, to signify these separate but overlapping scales of place in recognition of this state of things. 
gaze, filters out the extraneous detail, and concentrates the emotional impact of what it portrays" (59). Making use of such a lens outside of the buffering comfort zone of one's customary home environment can be a particularly effective means of coming to terms with alterity of space and culture, Einbeck goes on to argue (62). But is literature, and the term should be taken in a fairly broad, rather than traditional-elitist, sense here and throughout this essay, simply a reflection of place or a means of providing a vantage point from which to take stock of it, as Einbeck suggests?

Ground-breaking literary geographical theorist Bertrand Westphal challenges this prevalent notion in positing that literature is "the cornerstone of the imaginative project" of diachronically establishing a sense of place (33), that writing "does not mimic reality, but [rather] actualizes new virtualities hitherto unexpressed" (103). In other words, writing does not create a more or less accurate facsimile of a fixed, semantically cohesive place whose intrinsic meanings and other defining attributes are readily and matter-of-factly accessible through firsthand experience, as is commonsensically believed. Instead, over time writing and other forms of representational creative production, using the discursive means available to them, come to create a broad contestatory field of place meanings and identity tropes ${ }^{3}$ that become culturally diffuse over time. This is what Wallace Stegner means when he writes, "No place, not even a wild place, is a place until it has had that human attention that at its highest reach we will call poetry" (3): place is a cultural construct, one that is imaginatively pieced together out of the raw material of topography, architecture, phenomenological experience, and, most importantly, preceding representations of place. Thus it is by nature dialogical, in Mikhail Bakhtin's sense of the term: representing an object, such as a place, necessarily runs up against various other representation reflecting the various other ideological positions constitutive of a society, disputing and qualifying them as it is disputed and qualified in turn (277). That is, discursive fields are veritable battlefields of signification amongst which the "voices" of various social groups jockey for perspectival sway, but this same contestation occurs on the level of individual utterances, which can carry resonances of a multiplicity of social voices that cannot be monologically reconciled (Bakhtin 263). As Eric Prieto formulates this in reference to place:

Every geographical location has its own set of unique physical characteristics and its own history, but the identity and significance of each site may have more to do with the discursive meanings projected upon it than on its actual physical and historical constitution. Wherever there are multiple subjects, there are multiple meanings that will be in conflict with each other to a greater or lesser extent depending on circumstances. Any given site is going to be subject to dialogical struggle over the meaning of that site. (14)

Given this, study abroad students will not, any more than anyone else, encounter a coherent place that they can singularly come to apprehend through rigorous academic and experiential detective work. Christine Cozzens suggests something akin to this when, referencing Heinrich Boll,

${ }^{3}$ A trope is a figurative use of language used to evoke a short-form, coherent sense of some evoked object or subject. For example, New York City as the city that never sleeps and as Mammon, the dark god who devours the young, are two tropes that have variously been used to posit aspects of a sense of New York place. 
she asserts the subjective essence of place writing that "ultimately transcends the physical location" (149). However, this perspective offers up an entirely personal and relativistic take on the encounter with place, whereas this encounter is always mediated by preexistent representational traditions in a manner akin to that of the interpretive communities reader-response literary critics have theorized. When experience and study cause study abroad students to let go of their culture's grossly stereotypical projections of a place, they enter a fraught semantic terrain of competing identity tropes, metaphors, valuations, and so forth, that is, a range of dynamic senses of place forged in accordance with social groups' material experiences of a given locale over time.

Asking study abroad students to read/write intensively about place, then, is asking them to come to appreciate the multifariousness of place and take up evolving positions within the extant discourse of place. Doing so is an imaginative attempt to connect with a world of alterity, as Karen Rodriguez sees it (15), ${ }^{4}$ but again this is an alterity that is going to always be mediated by inherited cultural constructions of place--which raises the question of whose constructions. Bertrand Westphal distinguishes between endogenous, exogenous, and allogenous apprehensions of place: those (respectively) of native, foreign outsider, and foreign yet familiar/habituated (such as expatriate) populations (128). Without epistemologically privileging any of these over the others, Westphal argues that each one, plus the interactions between them, should be taken into account in analyzing how place is defined and experienced (129). Seen in this light, cultural constructions of place reflect what James Clifford observes about culture in general: that culture should be understood as "an openended, creative dialogue of subcultures, of insiders and outsiders, of diverse factions" (qtd in Chen 126). When study abroad students are asked to read and write about place, they are being asked to challenge and qualify their exogenous perspective through critically entertaining endogenous perspectives, as well as allogenous and other exogenous ones. That is, they are being asked to loosen their cultural blinders, not because there is an alternative definitive or unitary endogenous perspective on place available to them, but because the more multivalent and heterogeneous one's outlook on place is, the richer and more complex it is.

Leeann Chen signals a means towards this end when she suggests having students write about their host place for an audience (real or imagined) of native inhabitants (118): in asking students to think critically about perspective and how to relax one's myopia-inducing exogenous perspective in the name of avoiding giving offense, one can begin to foster a mindset that is more receptive to understanding difference and less prone to definitive snap judgments informed by one's native subject position and the biases that come with it. But what are some other ways that this understanding of the relationship of place to representational discourse can be put into concrete educational practice?

\footnotetext{
${ }^{4}$ Rodriguez highlights the vital importance of this project, given that study abroad students will return to their home countries as opinion leaders on the place of their sojourn, either countering or reinforcing commonsensical cultural stereotypes regarding this place, its customs, practices, values, and so forth (2).
} 


\section{Place Writing Praxis and a Sample Course of Study}

Many if not most successful study abroad programs make use of extensive place-based reading and writing to complicate and broaden students' understandings of their cross-cultural experiences. Given the socially produced, contestatory nature of place, what are some of the best means of doing so? Writing as a means of arriving at deeper and more nuanced conceptualizations of place can best be carried out hand-in-hand with concerted study of texts that have influentially attempted to define that place and texts that have done so in more idiosyncratic yet noteworthy manner. In Writing Across Culture, their influential guide to writing-to-learn in a study abroad context, Kenneth Wagner and Tony Magistrale recommend that students keep an "analytic notebook," featuring writing that is an admixture of expressive and transactional (i.e. informative) modes, as a key learning tool in study abroad (32-33). Such a notebook, they observe, can serve as a means of adjusting to culture shock, but apropos of the current discussion, it can also facilitate coming to an understanding of one's experience of place while simultaneously reconciling this experience with one's study of representations of place (42-46). In essence, this form of writing can transmute the stuff of raw experience of a foreign place into a set of tropes, narratives and so forth that enter into an ongoing process of dialectical revision as they are exposed to the sense of place formulated by other writers and consequently expanded upon, broadened, and otherwise revised. In this, the study abroad analytic notebook allows for mythopoesis on a personal, somewhat humble scale. ${ }^{5}$

But what does having students engage analytically in their writing with authors' representations of place entail? Doing so involves more than just taking into account the pronouncements of characters' and narrators' voice about place and how descriptions of physical environments establish setting -- though it does certainly require looking at these. Analyzing representations of place needs to move beyond this to consider the core array of tropes a text uses to give definition to a place, as well as the way that it imagines place in terms of the set of potential courses of action and modes of being that it makes possible. In the latter sense, a representation of place is a statement of what is understood to happen and be able to happen there. Taking account of this dynamic manner in which place is figured textually serves to help students enter into the complex discourse that conditions receptions of place, thus making them more sophisticated in their mode of relating to their study abroad site both a priori and during their sojourn.

There are numerous ways that a study abroad teacher can structure a sequence of readings to facilitate this process and numerous types of texts that can be drawn upon. Works of widely recognized literary merit can have the advantage of a certain depth and complexity in their representations of place, in addition to the fact that as canonical texts they have figured over time in

\footnotetext{
${ }^{5}$ It should not, however, be assumed that writing about place, capturing its constitutive elements and textures in language, will be something that study abroad students are comfortable with or have even attempted concertedly. Christine Cozzens recommends working with students prior to departure to develop rhetorical familiarity with representing place by practicing capturing in words sites that are familiar to them, such as parts of their campus and/or its surrounding area (157-8).
} 
the native population's place-based process of identity formation. ${ }^{6}$ But more popular sources can be useful too, especially given their wide currency/circulation, and just about any genre of writing can be used to give students a certain perspective on place.

The following outline of a sequence of readings for students to engage with in their analytic journals is offered as an illustration of one possible way the preceding considerations could be put into educational practice. The example of Paris was chosen because it remains one of the most popular study abroad destinations and because of the two years of experience I have had teaching the core "French Language and Culture" course there as part of the University of Louisiana Study Abroad Paris summer program.

Pre-departure: Early on in their program orientation students should be called on to take reflective stock of their preconceived notions of the place they will be encountering, particularly given how heavily laden the relationship between France and America is on both sides with both positive and negative strong cultural stereotypes. One way to do so is by having them respond in writing to the prompt "What is Frenchness/Parisianness and what is your relation to it, if any?" as an opening to their analytic notebooks.

From there, the course could proceed to consider exogenous and allogenous representations of Paris and France, those emanating from the subject of Americans encountering the place for a greater or lesser span of time and in a greater or lesser degree of depth from an American subject position similar to that of the program participants. This would allow students to engage with other minds faced with a similar situation of having to make sense of Paris and France from a similar kind of cultural remove, though often one informed by a lengthier period of exposure. Obvious reading selections here might include passages from Thomas Jefferson's autobiography (1809) and Mark Twain's Innocents Abroad (1869), such renowned Jazz Age expatriate writings as F. Scott Fitzgerald's "Babylon Revisited" (1931) and Ernest Hemingway's A Moveable Feast (1964), relevant African American expatriate literary selections like Langston Hughes's autobiography The Big Sea (1940) and James Baldwin's story "This Morning, This Evening, So Soon" (1965), and the work of such contemporary Americans in France as David Sedaris. It also might be useful, at this early program juncture, to grapple with the extreme romanticization of Paris by examining the often-playful multiperspectival take on the city offered by the film Paris, Je t'Aime (2006) as a means of opening up considerations of how popular notions of heavily mass-mediated places are disseminated and contested and of the essential multifariousness of place.

Arrival: On their initial exposure to their study abroad destination, students can benefit mightily from the conceptualizations of a place offered across the course of its spatial and cultural evolution by its lionized native writers. This sort of diachronic approach to representations of place

\footnotetext{
${ }^{6}$ On perhaps the national, regional, and/or local level of imaginary community (to use Benedict Anderson's term) narrative construction. Think, for example, of very different roles Margaret Mitchell's Gone with the Wind and William Faulkner's oeuvre have played in defining a sense of Southern place, or Thoreau and Hawthorne in doing so for New England.
} 
can illustrate how identity tropes persist over time and/or shift in their permutations, as well as how successive generations of writers reinforce or challenge the notions of place passed down to them. In the case of Paris, this process might begin with the beginnings of the modern era and Paris's increasing rise to prominence at the tail end of the Middle Ages. Either Francois Rabelais's playful take on the crowds and naming of the city in book one of Gargantua and Pantagruel or selected poems by Francois Villon could serve as a viable point of departure in this regard. From there the course could proceed in one of many directions. Its sequence of readings could be organized so as to chronologically trace the evolution of Parisian urbanism, from the construction projects of Napoleon I, to Haussmann's radical overhaul of the city's infrastructure and ruling aesthetic, to the transformations of the city enacted under Georges Pompidou and Francois Mitterand. But just as productively, this sequence could be arranged in terms of a number of themed "units," such as Paris and class struggle (with selections from Victor Hugo's Les Miserables (1862), Gustav Flaubert's $A$ Sentimental Education (1869), and Emile Zola's The Belly of Paris (1873)), Paris and the Belle Epoque (Zola's The Ladies' Paradise (1883), Marcel Proust's In Search of Lost Time (1913-1927), and short fiction by Guy de Maupassant and Colette), multicultural Paris (Julio Cortazar's Hopscotch (1963), Mehdi Charef's Tea in the Harem (1983), and Andrei Makine's Dreams of my Russian Summers (1995), Paris from the perspective of its slums (Louis-Ferdinand Céline's Journey to the End of the Night (1932) and/or Death on the Installment Plan (1936), George Orwell's Down and Out in Paris and London (1933), and Calixthe Beyala's Loukoum: The Little Prince of Bellville (1995)), to name just a few possibilities.

But however the pieces students are asked to read and engage with in their analytic notebooks are selected and presented, it is important that this not devolve into an exercise in literary tourism, where the students superficially encounter a famous literary work and then just as superficially visit a site or sites associated with it or its author. Rather, they are to consider how the assigned readings conceptualize place and thereby enter into the highly contestatory discursive field oriented around attributing meanings and senses of identity to said place. And in doing so, they will effectively be evaluating the representations of place they are encountering; judging if they were and/or continue to be sound, "trying on" those they might incorporate into their increasingly nuanced sense of place.

At the same time students will hopefully come to see the irreconcilability of a number of these conceptualizations of place, how taken in aggregate they form more of a cacophony than harmony, and in doing so come to a more relativistic understanding of the general nature of place identity. As Eric L. Ball and Alice Lai observe, students of place must "remain attentive to the political geography of difference not only among places, but within places" (qouted in McCracken 130). That is, they need to learn to be wary of the predominant cultural myths that feed into a hegemonic conceptualization of place that by nature occludes alternative conceptualizations, particularly those of marginalized social groups. In this regard, while canonical literary texts can be quite useful in helping students to arrive at increasingly sophisticated and nuanced conceptualizations of place, it is important to pull from a broadly inclusive canon of literary works rather than a narrow and traditionalist one so as to hold at arm's length the inherent perspectival biases of canons drawn 
exclusively from representatives of the dominant social group. After all, isn't the driving educational spirit behind the study abroad experience to meaningfully problematize students' notions of the place of their sojourn, of alterity, and of themselves?

\section{Conclusion: On the Social Character of Place}

In the test case sketched out above, students can illuminatingly come to see Paris as the historical march of the Parisians, of the spaces that they have put in place over time. The literature of a given place, studied in this diachronic manner, places in evidence the social activities, practices, and attitudes that make a place what it is. This way of arriving at an understanding of the social character of place through literature should be taken as one of many, in conjunction with those suggested above and others that the study abroad instructors and students collaborating on this process arrive at. It has the particular advantage, though, of connecting with another aspect of literary study that makes it an invaluable part of all forms of international learning: its capacity to foster the development of emotional intelligence. Patrick Sherlock argues that the central emotional intelligence skills of empathy and trans-subjective understanding are crucial to the cultural, political, and geographical boundary crossing mission that is at the heart of international education (148). In order for study abroad to "work," of course, educators have to find ways of encouraging students to relax their culturally conditioned ways of seeing and approach foreign societies and their representatives through a mode of deep human receptivity rather than one of prejudice and facile conceptual pigeonholing. In a recent empirical study David Comer Kidd and Emanuele Castano have found that as opposed to other types of reading, literary fiction improves the ability to empathize among its readers due to its ways of powerfully dramatizing the subjective states of being of various majority and minority social groups and its tendency to radically call into question appearances and hierarchies of value. So while opening up vistas of understanding regarding the social aspects of the place(s) they are to study and encounter, literary texts can also help students to become more receptive and consequently more ethically oriented towards the individuals they will encounter and the larger social groupings that these individuals represent. Again, the power these texts have to do so makes them an invaluable learning tool. As the United States stands here poised on the brink of sending one million of its students to study abroad each year, it can either send them as curious seekers fundamentally opened up by the understanding that there are significantly different realities faced by and productively responded to by people across lines of gender, ethnicity, ideology, and national identity, or it can send them as bigoted tourists thinly cloaked by a legitimizing veneer of academic affiliation. Which is more likely to produce "global citizens" and help pave the way to a more harmoniously internationalized world?

\section{Works Cited}

Bakhtin, Mikhail. The Dialogic Imagination. Trans. Caryl Emerson and Michael Holquist. Austin: U of Texas P, 1981..

Baldwin, James. "This Morning, This Evening, So Soon." Going to Meet the Man. New York: Random House, 1995: 145-193.

Beyala, Calixthe. Loukoum: The Little Prince of Bellville. Trans. Marjolijn De Jager. Portsmouth, NH: 
Heinemann, 1995.

Céline, Louis-Ferdinand. Death on the Installment Plan. Trans. Ralph Manheim. New York: New Directions, 1971.

........ Journey to the End of the Night. Trans. Ralph Manheim. New York: New Directions, 2006.

Charef, Mehdi. Tea in the Harem. Trans. Ed Emery. London: Serpent's Tail, 1989.

Chen, Leeann. "Writing to Host Nationals as Cross-Cultural Collaborative Learning in Study Abroad." Methods for Teaching Travel Literature and Writing: Exploring the World and Self. Ed. Eileen Groom. New York: Peter Lang, 2012: 117-135..

Colette. The Collected Stories of Colette. Trans. Antonia White, Matthew Ward, and Anne-Marie Callimachi. New York: Farrar, Straus, and Giroux, 1984..

Cortazar, Julio. Hopscotch: A Novel. Trans. Gregory Rabasssa. New York: Pantheon Books, 1987.

Cozzens, Christine S. "Writing Ireland: Travel Writing as Study and Practice for Students Going Abroad." Methods for Teaching Travel Literature and Writing: Exploring the World and Self. Ed. Eileen Groom. New York: Peter Lang, 2012: 149-163..

Einbeck, Kandace. "Using Literature to Promote Cultural Fluency in Study Abroad Programs." Unterrichtspraxis/Teaching German 35.1 (spring 2002): 59-67.

Fitzgerald, F. Scott. Babylon Revisited and Other Stories. New York: Scribner, 1996.

Flaubert, Gustav. Sentimental Education. Trans. Robert Baldick. New York: Penguin Books, 1964.

Hemingway, Ernest. A Moveable Feast. New York: Scribner, $1996 .$.

Hughes, Langston. The Big Sea: An Autobiography. New York: Hill and Wang, 2001.

Hugo, Victor. Les Misérables. Trans. Lee Fahnestock andNorman MacAfee. New York: Penguin Books, 1987.

Jefferson, Thomas. Autobiography of Thomas Jefferson. Chehalis, WA: Big Fish Pub., 2010.

Kidd, David Comer and Castano, Emanuele. "Reading Literary Fiction Improves Theory of Mind." Science 342.6156 (October 2013): 377-380.

Lefebvre, Henri. The Production of Space. Trans. Donald Nicholson Smith. Cambridge, MA:

Blackwell, 1991.

Makine, Andrei. Dreams of my Russian Summers. Trans. Geoffrey Strachan. New York: Arcade Pub., 2011.

Maupassant, Guy de. Collected Short Stories. New York: Barnes and Noble Classics, 2008.

McCracken, Ila Moriah. Locating Place in Writing Studies: An Investigation of Professional and Pedagogical Place-Based Effects. Ann Arbor: Proquest, 2008.

McKeown, Joshua S. The First Time Effect: The Impact of Study Abroad on College Student Intellectual Development. Albany: SUNY Press, 2009.

Orwell, George. Down and Out in Paris and London. Orlando: Mariner Books, 1972. Print.

Paris, Je t'Aime. Dir. Olivier Assayas et al. Canal +, 2006. Film.

Prieto, Eric. Literature, Geography, and the Postmodern Poetics of Place. New York: Palgrave MacMillan, 2013..

Proust, Marcel. In Search of Lost Time. Trans. C.K. Scott Moncrieff, Terence Kilmartin, and Andreas Mayor. New York: Random House, 2003.

Rabelais, Francois. Gargantua and Pantagruel. Trans. Burton Raffel. New York: W.W. Norton \& Co., 1991.

Redden, Elizabeth. "International Study Up." Inside Higher Ed. 11 November 2013. Web. 15 February 2014.

Rodriguez, Karen. "Experiences with Poetry, Pedagogy and Participant Observation: Writing with 
Students in a Study Abroad Program." International Journal of Education and the Arts 7.1 (March 2006): 1-19.

Sedaris, David. Me Talk Pretty One Day. Boston: Back Bay Books, 2001.

Sherlock, Patrick. "Emotional Intelligence in the International Curriculum." Journal of Research in International Education 1.2 (December 2002): 139-158.

Stegner, Wallace. “The Sense of Place.” The Sense of Place. New York: Random House, 1992: 1-4.

Tally Jr., Robert T. "Introduction: On Geocriticism." Geocritical Explorations: Space, Place, and Mapping in Literary and Cultural Studies. Ed. Robert T. Tally Jr. New York: Palgrave MacMillan, 2011: 1-9.

Trooboff, Stevan et al. "Employer Attitudes toward Study Abroad." Frontiers: The Interdisciplinary Journal of Study Abroad (winter 2007): 17-34.

Tuan, Yi Fu. Space and Place. Minneapolis: U of Minnesota P, 1977.

Twain, Mark. The Innocents Abroad. London: Wordsworth Classics, 2010..

Villon, Francois. The Complete Works of Francois Villon. Trans. Anthony Bonner. New York: Bantam Books, 1960.

Wagner, Kenneth and Magistrale, Tony. Writing across Culture: An Introduction to Study Abroad and the Writing Process. New York: Peter Lang Pub., 1995.

Wanner, Dieter. "Study Abroad and Language: From Maximal to Realistic Models." The Handbook for Practice and Research in Study Abroad: Higher Education and the Quest for Global Citizenship. Ed. Ross Lewin. New York: Routledge, 2009: 81-98..

Westphal, Bertrand. Geocriticism: Real and Fictional Spaces. Trans. Robert T. Tally Jr. New York: Palgrave Macmillan, 2011.

Zola, Emile. The Belly of Paris. Trans. Mark Kurlansky. New York: Modern Library Classics, 2009. The Ladies' Paradise. Trans. Brian Nelson. Oxford: Oxford UP, 2008. 